\title{
More Money: Understanding Recent Changes in the Monetary Base
}

\author{
William T. Gavin
}

\begin{abstract}
The financial crisis that began in the summer of 2007 took a turn for the worse in September 2008. Until then, Federal Reserve actions taken to improve the functioning financial markets did not affect the monetary base. The unusual lending and purchase of private debt was offset by the sale of Treasury securities so that the total size of the balance sheet of the Fed remained relatively unchanged. In September, however, the Fed stopped selling securities as it made massive purchases of private debt and issued hundreds of billions of dollars in short-term loans. The result was a doubling of the size of the monetary base in the final four months of 2008. This article discusses the details of the programs that the Fed has initiated since the crisis began, shows which programs have grown as the monetary base grew, and discusses some factors that will determine whether this rapid increase in the monetary base will lead to rapid inflation. (JEL E31, E42)
\end{abstract}

Federal Reserve Bank of St. Louis Review, March/April 2009, 91(2), pp. 49-59.

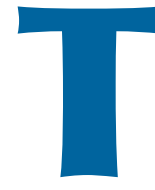

he monetary base is the sum of currency in circulation and bank deposits at Federal Reserve Banks. Between midSeptember and December 31, 2008, the U.S. monetary base increased from approximately $\$ 890$ billion to $\$ 1,740$ billion, doubling in a little more than 3 months. ${ }^{1}$ This is a concern because, under normal circumstances, we would associate such a rapid rise in the monetary base with a sharp acceleration of inflation. But today, more people seemed to be worried about deflation than a sudden rebound of inflation. The purpose of this article is to explore the sources of growth in the monetary base and to ask whether or not

\footnotetext{
1 These data are derived from the Fed's H4.1 release (www.federalreserve.gov/releases/h41/). This measure of the monetary base is named as the series WSBASE on the Federal Reserve Bank of St. Louis's FRED database. For technical reasons (adjustments for seasonal factors, reserve requirements, carryover, "as of," and cash items in process of collection), the numbers here do not correspond to either the Board of Governor's measure of the monetary base on the $\mathrm{H} 3$ release or the St. Louis adjusted monetary base.
}

we should expect to see high inflation following such rapid monetary growth.

Figure 1 shows that this rapid surge in the monetary base is concentrated entirely in the accumulation of bank reserves. (Throughout this article, the generic word "bank" is used instead of the official term, "depository financial institution.") Bank deposits at the Fed include three components. Two are small and have changed little since the economic crisis began in August 2007; they are deposits used to satisfy reserve requirements and those used to satisfy required clearing balances. ${ }^{2}$ The third component, "excess reserves," accounts for the doubling of the monetary base. This rapid increase is directly related to Federal Reserve programs initiated or expanded

\footnotetext{
2 See Stevens (1993) for a description of required clearing balances. See Anderson and Rasche (2001) for a description of the sweep programs that reduced the amount of required reserves essentially to that which would normally be held as a buffer for clearing checks and meeting uncertain cash withdrawals.
}

William T. Gavin is a vice president and economist at the Federal Reserve Bank of St. Louis. The author thanks Dick Anderson, Bob Rasche, and Dave Kemme for helpful comments. Chris Martinek provided research assistance.

(C) 2009, The Federal Reserve Bank of St. Louis. The views expressed in this article are those of the author(s) and do not necessarily reflect the views of the Federal Reserve System, the Board of Governors, or the regional Federal Reserve Banks. Articles may be reprinted, reproduced, published, distributed, displayed, and transmitted in their entirety if copyright notice, author name(s), and full citation are included. Abstracts, synopses, and other derivative works may be made only with prior written permission of the Federal Reserve Bank of St. Louis. 
since September that seek to improve the functioning of financial markets under stress.

Since lowering its federal funds rate target to the range of 0 to 0.25 percent, the Federal Open Market Committee (FOMC) has referred to its latest policy actions as "credit policy." These new programs are distinguished from traditional monetary policy by the type of assets purchased by the Federal Reserve. Traditional programs involve the purchase and sale of U.S. Treasury securities, whereas the new credit-oriented policies involve the purchase of non-Treasury securities, including commercial paper and asset-backed securities. By purchasing such assets, the Fed hopes to reduce risk premiums and improve flows through the specific private markets (Bernanke, 2009). Yet, although the emphasis of these credit programs is on the types of non-Treasury securities being purchased (that is, the composition of the Fed's assets), nontraditional and traditional programs share one common characteristic: The purchase of any asset by the Fed, unless offset by some other action, increases simultaneously both the Fed's balance sheet assets and its liabilities.

The next section of this article shows the Fed's balance sheet in January 2007 and again in January 2009, highlighting the balance sheet changes since the summer of $2007 .{ }^{3}$ It highlights the new programs and shows which have contributed most to the recent surge in the monetary base. The following section then discusses economic and institutional factors that will influence the Fed's ability to maintain price stability as the economy recovers from the recession and the financial crisis.

\section{THE FED'S BALANCE SHEET- BEFORE AND AFTER}

It would be an error to believe that the Fed's new programs to improve the functioning of credit markets began only in September 2008; they did

\footnotetext{
3 See Balbach and Burger (1976) for an elementary introduction to the derivation of the monetary base from the central bank's balance sheet. Their appendix includes an application of their method to the Fed's balance sheet in 1976. See Anderson and Rasche (1996) for the technical details in the derivation of the St. Louis adjusted monetary base.
}

not. But a major change did occur in September: The Fed stopped selling Treasury securities as it increased lending to financial institutions and purchased non-Treasury assets. As Figure 1 shows, before mid-September 2008, the Fed's practice of selling Treasuries as it purchased other financial instruments largely insulated the monetary base from these new programs-bank deposits at the Fed increased little. ${ }^{4}$

Table 1 presents a somewhat simplified view of the Fed's balance sheet to help illustrate the sources and uses of the monetary base today. ${ }^{5}$ The big changes in the traditional items on the asset side of the balance sheet are in outright holdings of Treasury securities, which fell from $\$ 778.9$ billion in 2007 to $\$ 475.2$ billion in 2009 . This has virtually wiped out the Fed's holdings of Treasury bills, which fell from $\$ 277$ billion to $\$ 18.4$ billion. The Fed's holding of notes and bonds was reduced from $\$ 467.9$ billion to $\$ 412.9$ billion. But of those the Fed still holds, $\$ 125.1$ billion has been lent through the Term Securities Lending Facility (TSLF) to securities dealers. Note that changes in the TSLF do not affect the size of the balance sheet, but they do reduce the liquidity of the Fed's security portfolio.

Holdings of federal agency debt rose from 0 to $\$ 26.7$ billion. Note that in December 2008, the FOMC authorized the Trading Desk of the Federal Reserve Bank of New York to purchase up to $\$ 100$ billion of agency debt in the first half of 2009. Repurchase agreements (repos) decreased from $\$ 27.5$ billion to $\$ 17.1$ billion. Another big change among the traditional assets was the big increase in primary lending: from $\$ 0.3$ billion in the week ending January 17,2007 , to $\$ 65.0$ billion in the week ending January 28, 2009. A new part of this lending program was the very public campaign to eliminate the "stigma" associated with borrowing at the discount window, an obstacle to overcome if these lending facilities were to be implemented as intended.

\footnotetext{
4 See Thornton (2009).

5 This information can be found in the H4.1 release in the table showing factors that supply and absorb reserves. These factors are found primarily on the Fed's balance sheet, but also include monetary items from Treasury's balance sheet.
} 


\section{Figure 1}

\section{Monetary Base}

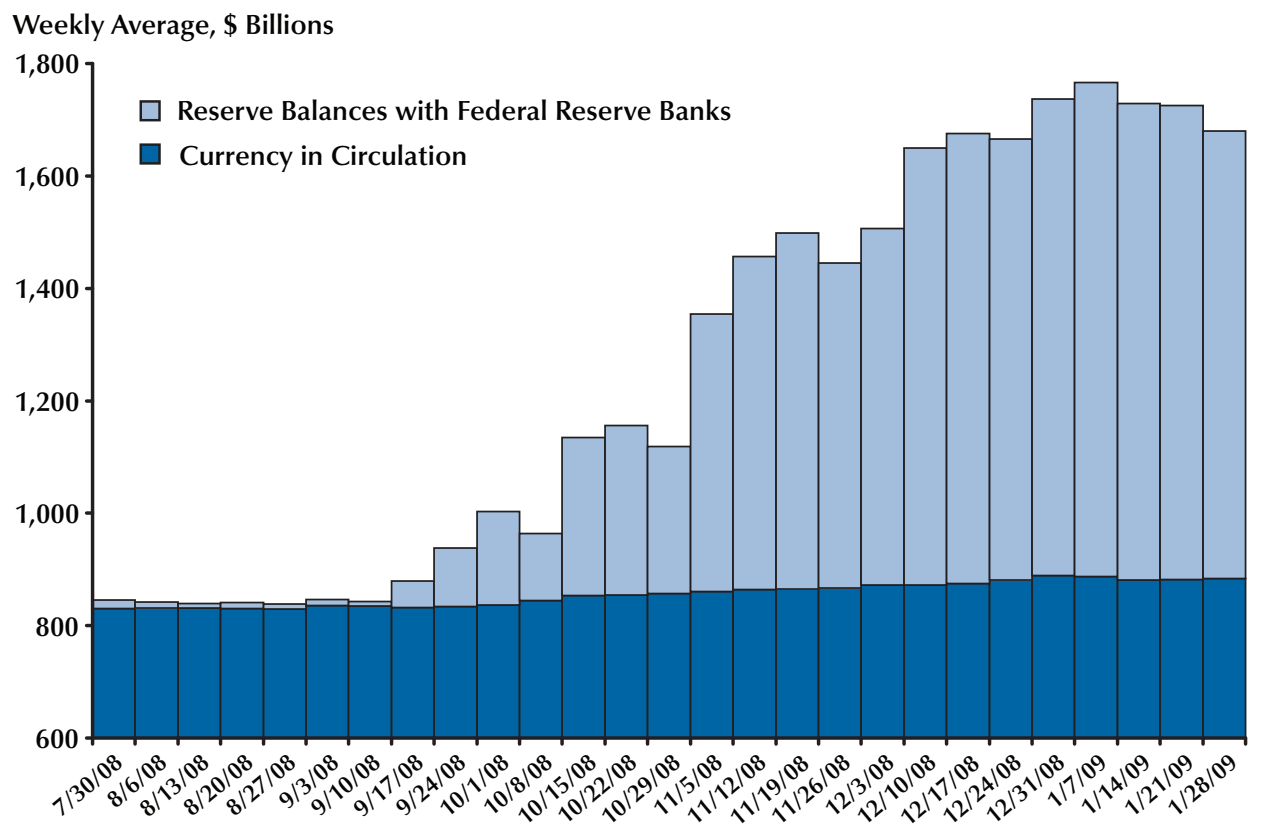

From January 17, 2007, to January 28, 2009, the traditional items on the asset side of the balance sheet decreased by $\$ 224.5$ billion. The decline in outright holdings of Treasury securities, repos, and float was partially offset by increases in primary lending and federal agency debt. The other longtime items on the balance sheet are either unchanged or relatively small. These include the gold stock, special drawing rights, other assets, lending through the traditional channels, secondary and seasonal lending, and float.

Next, we turn to the new programs established after the crisis began. The Trading Desk has just begun to buy mortgage-backed securities (adding $\$ 6.8$ billion as of January 28,2009 ) under instructions from the FOMC to purchase as much as $\$ 500$ billion in the first half of 2009 . Also included on the balance sheet is a total of $\$ 415.9$ billion in loans to banks through the Term Auction Facility (TAF). ${ }^{6}$ Figure 2 shows the history of lending

\footnotetext{
6 For information about the acronyms and new programs, go to www.federalreserve.gov/newsevents/recentactions.htm.
}

under this program initiated in December 2007the same time that the Fed began lending securities to primary dealers through the TSLF.

On January 28, 2009, there were $\$ 32.1$ billion in loans outstanding in the Primary Dealer Credit Facility (PDCF) and other broker-dealer loans, $\$ 14.6$ billion in loans through the Asset-Backed Commercial Paper Money Market Mutual Fund Liquidity Facility (AMLF), and $\$ 38.3$ billion in direct loans to the American Insurance Group (AIG). Figure 3 shows the history of lending under these three new programs, as well as the traditional discount window lending of primary credit.

Certain new programs operate as specialpurpose vehicles (SPVs) wholly owned by the Federal Reserve Bank of New York. The assets and liabilities of these SPVs are included on the Federal Reserve's balance sheet. The next item in Table 1 (under "New program portfolio") is the sum of the private assets purchased under new programs; the total was $\$ 389.9$ billion the week ending January 28, 2009. Among these SPVs is the Commercial Paper Funding Facility (CPFF) 


\section{Gavin}

\section{Table 1}

\section{Factors Affecting Reserve Balances (\$ billions)}

\section{Week Ending}

\begin{tabular}{|c|c|c|}
\hline & \multicolumn{2}{|c|}{ Week Ending } \\
\hline & January 17, 2007 & January 28, 2009 \\
\hline \multicolumn{3}{|l|}{ Assets supplying reserves } \\
\hline Gold stock & 11.0 & 11.0 \\
\hline Special drawing rights & 2.2 & 2.2 \\
\hline Treasury securities* & 778.9 & 475.2 \\
\hline Bills & 277 & 18.4 \\
\hline Notes and bonds (nominal) & 467.9 & 412.9 \\
\hline Notes and bonds (inflation-indexed) & 30.2 & 39.4 \\
\hline Inflation compensation & 3.8 & 4.5 \\
\hline Federal agency debt & 0 & 26.7 \\
\hline Mortgage-backed securities & $\mathrm{NA}(01 / 05 / 09)^{\dagger}$ & 6.8 \\
\hline Repurchase agreements & 27.5 & 17.1 \\
\hline Term Auction Facility (TAF) ${ }^{\ddagger}$ & NA $(12 / 17 / 07)$ & 415.9 \\
\hline Loans and discounts including float & 0.1 & 148.0 \\
\hline Primary & 0.3 & 65.0 \\
\hline Secondary & 0.0 & 0.0 \\
\hline Seasonal & 0.0 & 0.0 \\
\hline Float & -0.2 & -2.0 \\
\hline Primary Dealer Credit Facility (PDCF) and other broker-dealer loans & NA $(03 / 17 / 08)$ & 32.1 \\
\hline $\begin{array}{l}\text { Asset-Backed Commercial Paper (ABCP) } \\
\text { Money Market Mutual Fund (MMMF) Liquidity Facility (AMLF) }\end{array}$ & NA $(09 / 19 / 08)$ & 14.6 \\
\hline Loans to American Insurance Group (AIG) & NA $(09 / 16 / 08)$ & 38.3 \\
\hline New program portfolio & - & 389.9 \\
\hline Commercial Paper Funding Facility (CPFF) & NA $(10 / 27 / 08)$ & 316.2 \\
\hline Money Market Investor Funding Facility (MMIFF) & NA $(11 / 24 / 08)$ & 0.0 \\
\hline Maiden Lane & NA $(06 / 26 / 08)$ & 27.0 \\
\hline Maiden Lane II & NA $(11 / 10 / 08)$ & 19.7 \\
\hline Maiden Lane III & NA $(11 / 25 / 08)$ & 27.0 \\
\hline Central bank liquidity swaps & NA $(12 / 12 / 07)$ & 465.9 \\
\hline Other assets & 39.6 & 44.4 \\
\hline \multicolumn{3}{|l|}{ Memo item } \\
\hline Treasury coin outstanding (TCO) & 38.3 & 38.8 \\
\hline Total factors supplying reserves $=$ Total assets + TCO & 897.5 & $2,041.9$ \\
\hline
\end{tabular}




\section{Table 1, cont'd}

\section{Factors Affecting Reserve Balances (\$ billions)}

\begin{tabular}{|c|c|c|}
\hline & \multicolumn{2}{|c|}{ Week Ending } \\
\hline & January 17, 2007 & January 28, 2009 \\
\hline \multicolumn{3}{|l|}{ Liabilities absorbing reserves } \\
\hline Federal Reserve notes held by Treasury & 0.2 & 0.3 \\
\hline Reverse repos, international accounts, and dealers (RRP) & 30.5 & 73.1 \\
\hline Treasury deposits & 4.7 & 230.4 \\
\hline General account & 4.7 & 55.5 \\
\hline Supplemental financing account & NA $(09 / 17 / 08)$ & 174.8 \\
\hline Foreign official & 0.1 & 0.2 \\
\hline Service-related and other demand deposits & 7.2 & 7.9 \\
\hline Other liabilities and capital & 36.7 & 50.4 \\
\hline Total factors other than the monetary base absorbing reserves & 79.4 & 362.3 \\
\hline Monetary base & 818.1 & $1,679.6$ \\
\hline Currency in the hands of the public (in circulation) & 757.6 & 830.6 \\
\hline Vault cash in depository institutions & 50.3 & 53.5 \\
\hline Counted as required reserves & 32.3 & 41.2 \\
\hline Counted as surplus cash & 18 & 12.3 \\
\hline Depository institution reserve balances & 10.2 & 795.5 \\
\hline Held as required reserves & 6.1 & 26.3 \\
\hline Held as excess reserves & 4.1 & 769.2 \\
\hline Total liabilities plus Treasury coin outstanding & 897.5 & $2,041.9$ \\
\hline \multicolumn{3}{|c|}{$\begin{array}{l}\text { NOTE: Components may not sum to totals because of rounding. Data are from the H4.1 release (Federal Reserve Statistical Release: } \\
\text { Factors Affecting Reserve Balances); see www.federalreserve.gov/releases/h41/. } \\
\text { *Includes } \$ 125.1 \text { billion lent to primary dealers through the Term Securities Lending Facility. } \\
{ }^{+} \text {NA refers to an item that was created after the financial crisis was under way. The date refers to the day that the Fed announced the } \\
\text { program or began to purchase this asset. }\end{array}$} \\
\hline
\end{tabular}

created to support activity in the market for the highest-rated (A1/P1) commercial paper. This program, created in the aftermath of the troubles at AIG, Lehman Brothers, and Merrill Lynch, has grown rapidly to $\$ 316.2$ billion, with the Fed providing most of the new lending in this market. Also included are three new structured investment vehicles created to buy and hold certain troubled assets of specific insolvent institutions. Through Maiden Lane, the Fed owns $\$ 27.0$ billion of the poorer-quality assets from the troubles at Bear Stearns. Through Maiden Lane II and Maiden Lane III, it owns $\$ 19.7$ billion and $\$ 27.0$ billion, respectively, of troubled assets purchased in sup- port of the insurance firm AIG. Figure 4 shows the history of assets purchased under these new programs.

On December 12, 2007, the Federal Reserve established temporary swap lines with foreign central banks. Under these swap arrangements, the Federal Reserve provides U.S. dollar deposits at the Federal Reserve in exchange for an amount of foreign currency deposits at the foreign central bank. The amount is determined by the prevailing exchange rate. The currency is swapped back at a future date at the swap exchange rate used in the original transaction. All exchange rate risk is the burden of the borrowing central bank. Figure 5 


\section{Gavin}

Figure 2

\section{Term Auction Facility Assets}

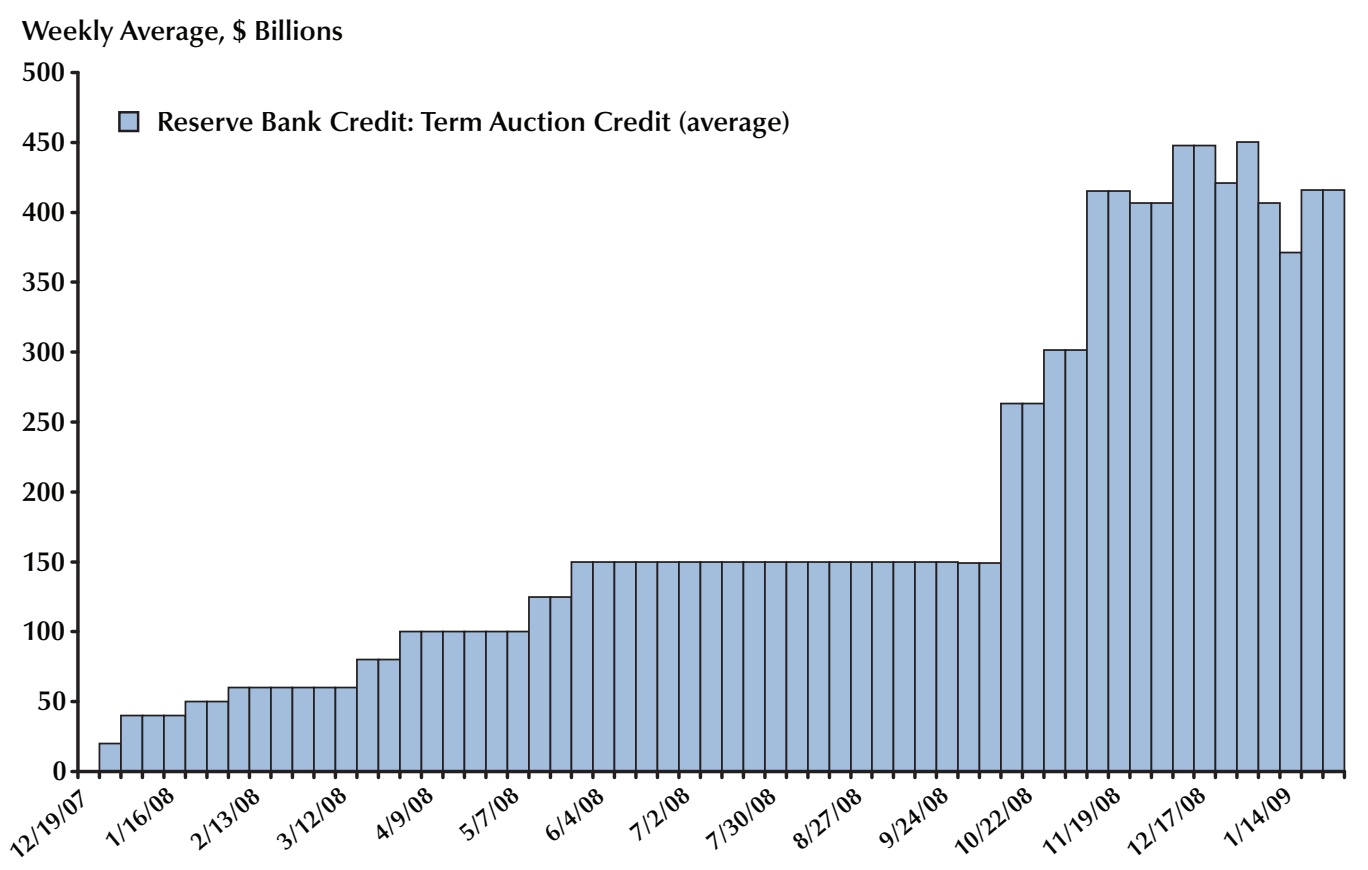

\section{Figure 3}

\section{Total Loans and Discounts}

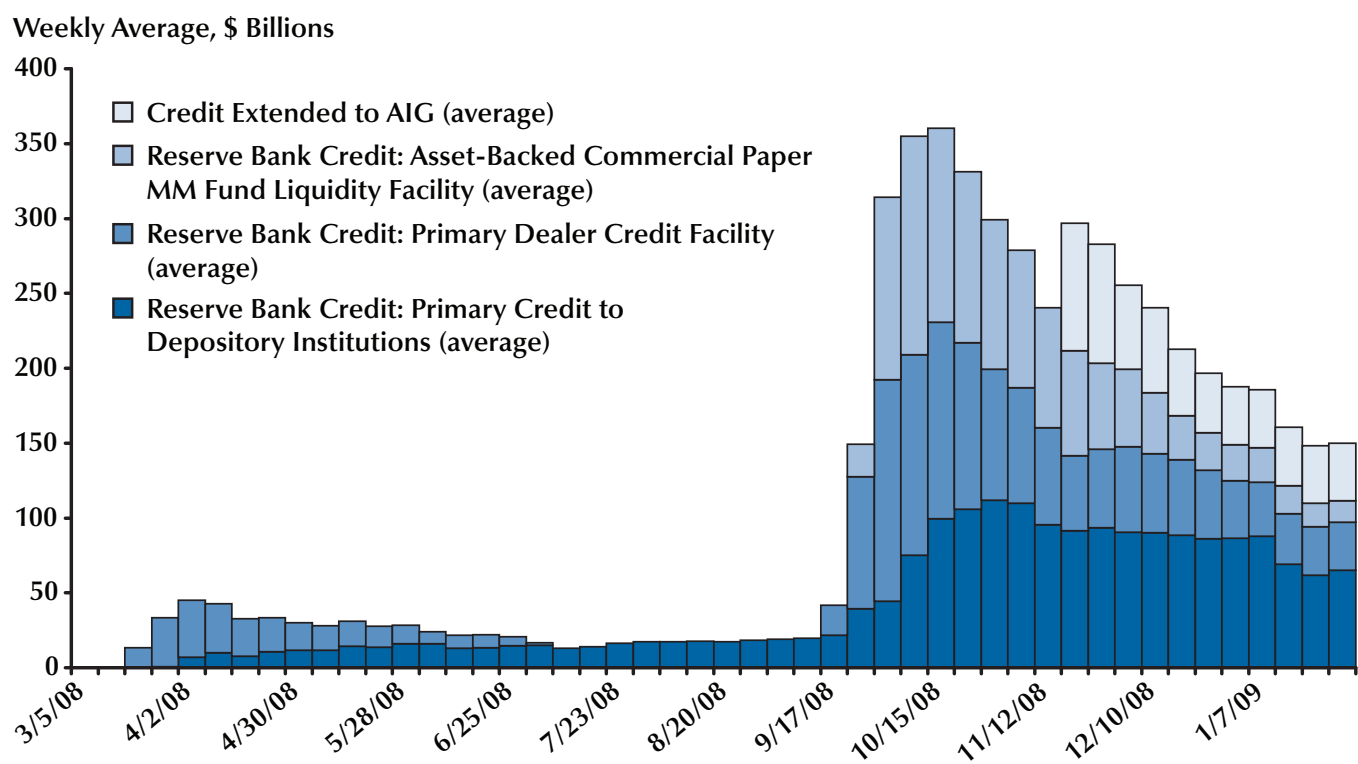


Figure 4

\section{New Program Portfolio}

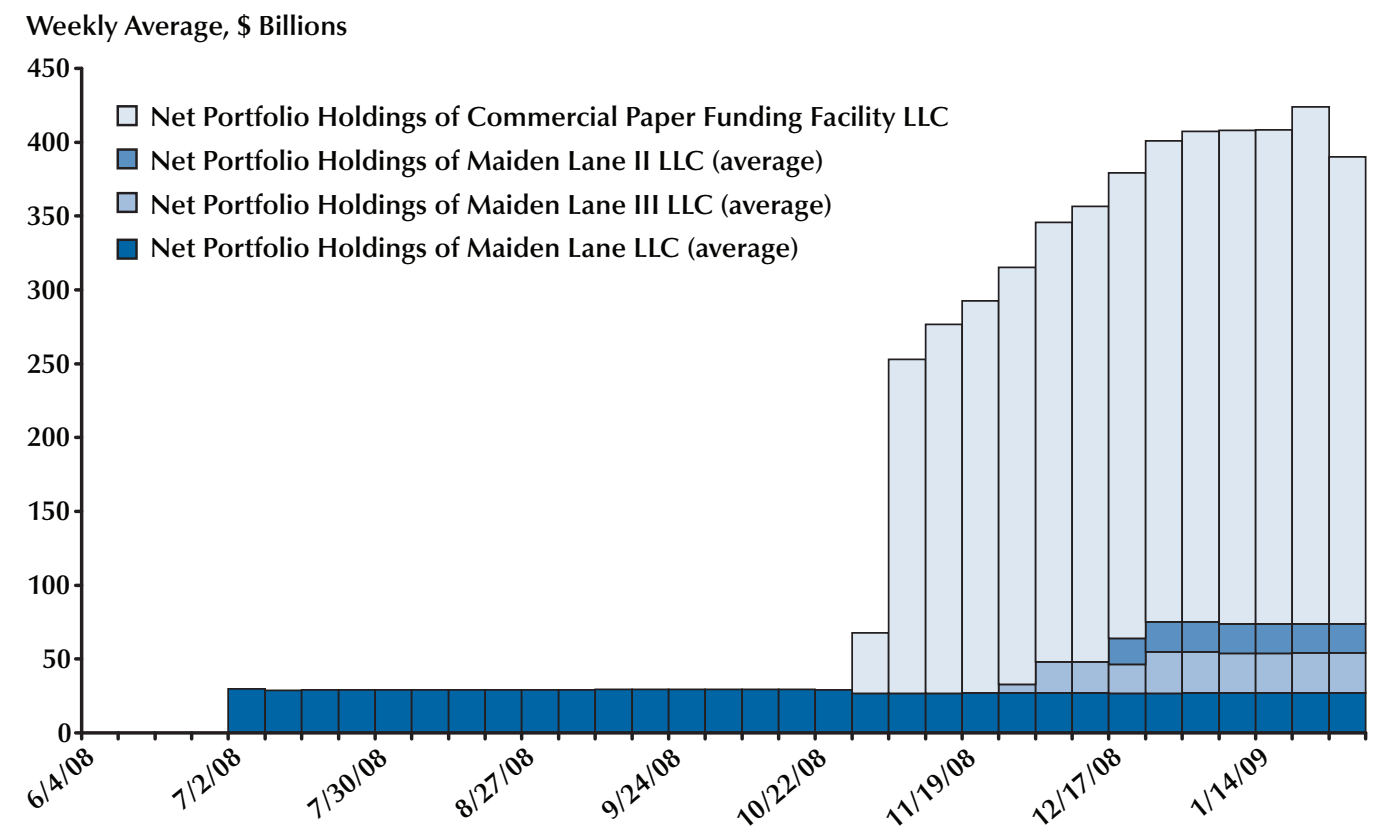

Figure 5

\section{Foreign Exchange Swaps}

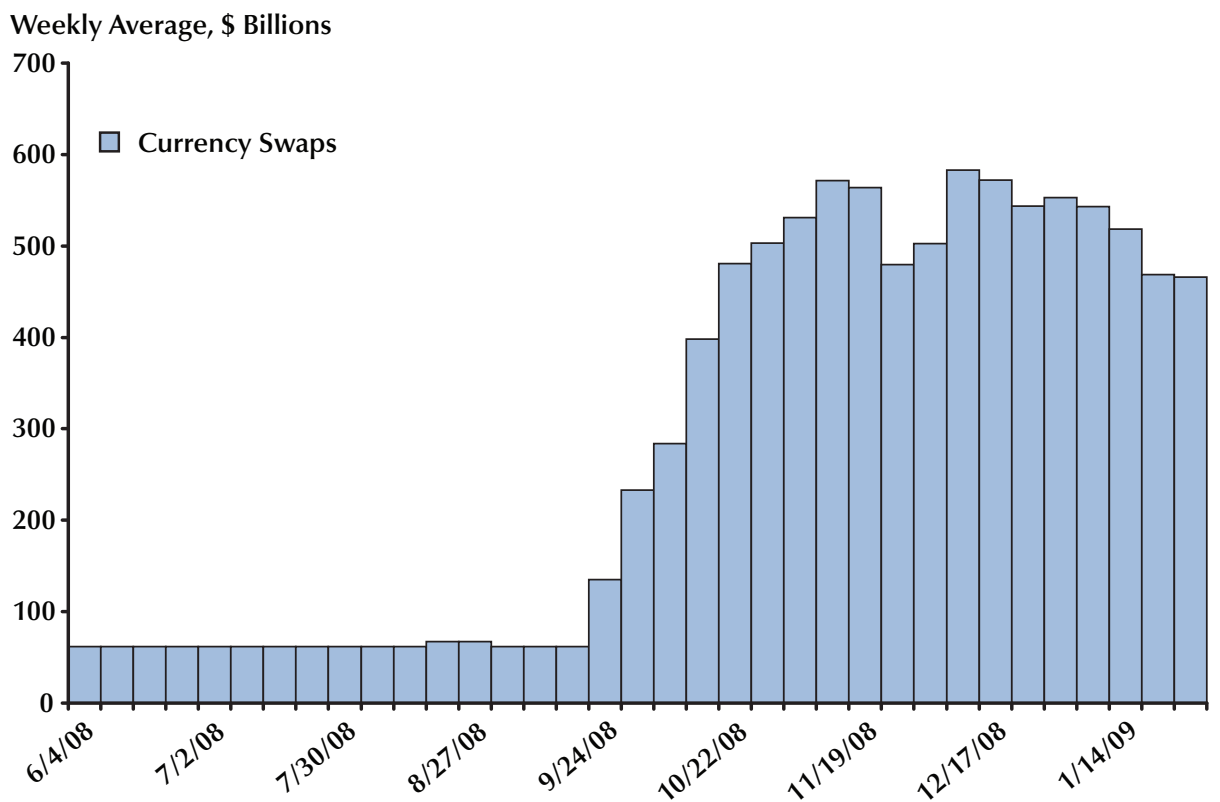




\section{Figure 6}

\section{Total Factors Other than Monetary Base Absorbing Reserves}

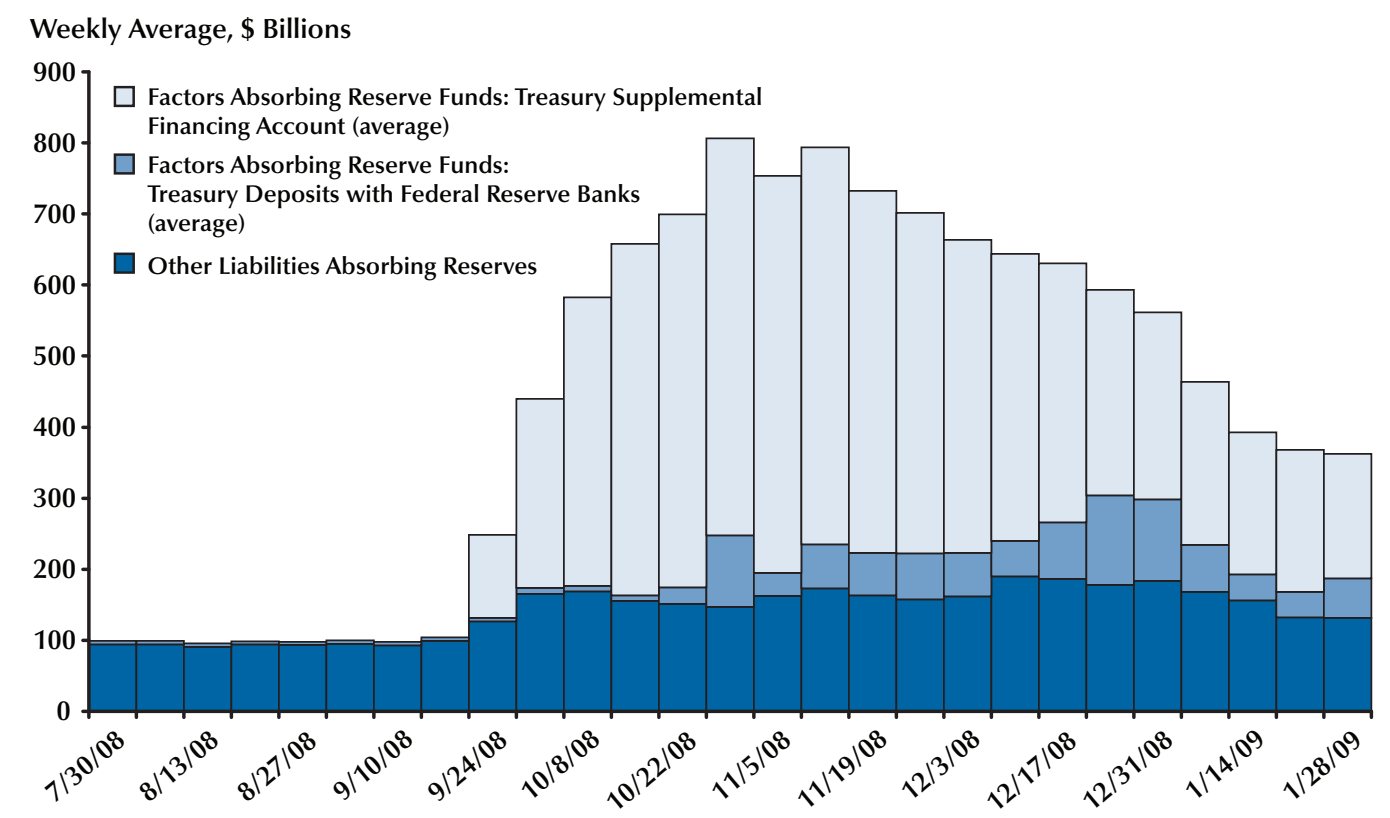

shows the dramatic rise in foreign exchange assets from currency swap arrangements; these swaps totaled $\$ 465.9$ billion as of the week ending January 28, 2009.

Overall, total assets added by the Federal Reserve's nontraditional credit programs were \$1,363.5 billion the week ending January 28, 2009. Total factors supplying monetary base skyrocketed that week to a little more than $\$ 2$ trillion, with almost all the increase coming after mid-September 2008.

Next, we turn to the liability side of the Fed's balance sheet. Not all liabilities of the Fed are included in the monetary base. Most items on the liability side of the Fed's balance sheet that are not included in the monetary base are small or relatively unchanged. There has been a relatively large increase-from $\$ 30.5$ billion to $\$ 73.1$ billion-in reverse repos with dealers, foreign official, and other international accounts. The other-and the most important item absorbing reserves-is the Treasury deposit account. The
Treasury general account rose from $\$ 4.7$ billion to $\$ 55.5$ billion; for more than 20 years, the Fed has maintained its general account (used for tax collection and government disbursements) near a $\$ 5$ billion balance. In September 2008, the Treasury created a new "supplemental financing account," which held $\$ 174.8$ billion on January 28,2009 . At inception, this account held $\$ 500$ billion obtained by the Treasury as proceeds from selling a special issue of Treasury bills to the public. The mechanism for this sale was quite simple: Each purchaser of a Treasury bill paid with a bank check or debit. When these transactions cleared, the Federal Reserve transferred the amounts from bank deposits (reserve accounts) to the Treasury account (which absorbs reserves, but is not part of the monetary base). In the second half of January, the Treasury allowed the special issue of Treasury bills to mature, to avoid hitting statutory debt limits. As the Treasury repaid the owners of these bills, deposits were transferred from the Treasury's deposits at the Fed to the 
deposits of the banks whose customers owned the maturing bills. Doing so increases the monetary base, dollar for dollar.

Overall, other factors absorbing reserves rose from $\$ 79.4$ billion in January 2007 to $\$ 362.3$ billion in January 2009. Figure 6 shows the total factors other than the monetary base that absorb reserves, with detail shown for Treasury deposits (both the general account and the supplemental financing account).

The bottom section in Table 1 lists the components of the monetary base. The "monetary base" is defined as currency in circulation and bank demand deposits at the Fed. Currency in circulation includes vault cash (coin and Federal Reserve notes held by the depository institutions) and cash held by the general public. Bank reserve deposits are sometimes referred to as federal funds. Thus, the federal funds rate is the interest rate that banks pay to borrow Federal Reserve deposits from other banks. The monetary base includes coin and Federal Reserve notes held overseas because we have no measure of the amount held overseas, only the total amount outstanding. ${ }^{7}$ And, regardless of where they are held, Federal Reserve notes are a liability of the Fed.

Between January 17, 2007, and January 28, 2009 , currency in the hands of the public grew from $\$ 757.6$ billion to $\$ 830.6$ billion. Vault cash grew from $\$ 50.3$ billion to $\$ 53.5$ billion. In January $2007, \$ 32.3$ billion of the vault cash was used to meet reserve requirements; in January 2009, \$41.2 billion of vault cash was used. In the early period, $\$ 18.0$ billion of vault cash was counted as surplus vault cash; in January 2009, $\$ 12.3$ billion was counted as surplus vault cash.

The interesting change in the monetary base was in reserve balances held in demand deposits at the Federal Reserve. These deposits grew from $\$ 10.2$ billion the week ending January 17, 2007, to $\$ 795.5$ billion the week ending January 28 , 2009. Of this large amount, $\$ 769.2$ billion was held as excess reserves at the Fed.

\footnotetext{
7 See Porter and Judson (1996) for estimates of the amount of cur-
} rency held abroad.

\section{WILL RAPID GROWTH IN THE MONETARY BASE CAUSE RAPID INFLATION?}

The enormous accumulation of excess reserves began at the time of the Lehman bankruptcy and rescue of AIG in mid-September. Whether this large increase in the monetary base is a harbinger of rapid inflation in the future depends on how the Federal Reserve and the U.S. government act when financial markets return to more-normal behavior and the recession ends.

The difficulty of maintaining price stability will depend on the size the balance sheet reaches before the crisis ends, the quality of the assets in the portfolio, and the policy followed to manage the interest rate paid on reserves. Any attempt to predict whether inflation will occur must rely on predictions about the Fed's response to events and its exit from these new programs (that is, reducing the size of the balance sheet) as the economy recovers from recession and financial crisis.

Analysis of future monetary policy must consider the October 1, 2008, Congressional authorization for the Fed to pay interest to banks on both required reserve and excess reserve balances. By increasing this rate relative to the federal funds rate target, the Fed provides an incentive for banks to hold more deposits at the Fed. By reducing this rate the Fed encourages banks to expand their lending-and the money supply. When the FOMC set the federal funds rate target to the range 0 to $1 / 4$ percent on December 16, 2008, it also set the interest paid on both required and excess reserves equal to $1 / 4$ percent.

A logical question might be why depository institutions would choose to hold $\$ 800$ billion in excess reserves that are earning so little. Two answers are important, one at the level of the individual bank and one at an aggregate level. First, for the individual bank, the risk-free rate of $1 / 4$ percent must be the bank's perception of its best investment opportunity. Note that on January 28, 2009, the interest rate on the 3-month Treasury bill was less than $1 / 4$ percent. The other is that, perhaps because of market conditions-the dramatic decline in the price of bank stocks and the fall in the market value of assets - the bank finds 
Table 2

\section{New Program Use and Authorization (\$ billions)}

\begin{tabular}{lcc} 
Assets supplying reserves & $\begin{array}{c}\text { Week ending } \\
\text { January 28, 2009 }\end{array}$ \\
\hline Mortgage-backed securities & 500 & 6.8 \\
Term Auction Facility (TAF) & 600 & 415.8 \\
Primary Dealer Credit Facility (PDCF) & No announced limit & 32.1 \\
Asset-Backed Commercial Paper (ABCP) Money Market & No announced limit & 14.6 \\
$\quad$ Mutual Fund (MMMF) Liquidity Facility (AMLF) & 60 & 38.3 \\
Loans to American Insurance Group (AIG) & No announced limit & 316.2 \\
Commercial Paper Funding Facility (CPFF) & 540 & 0 \\
Money Market Investor Funding Facility (MMIFF) & 29 & 27.0 \\
Maiden Lane & 22.5 & 19.7 \\
Maiden Lane II & 30 & 27.0 \\
Maiden Lane III & No announced limit & 465.9 \\
Swaps & &
\end{tabular}

itself undercapitalized. In such conditions, the bank is likely to hold relatively more safe assets while it builds capital by cutting costs, raising fee income, and hoping for a recovery in both the economy and its stock price.

Second, the banking system as a whole cannot create or destroy bank deposits at the Fed. Only the Fed (and technically, the Treasury) can create or destroy bank reserves. If one bank makes a loan and the funds are deposited in another bank, then the ownership of the deposits at the Fed would change, but the total bank deposits at the Fed would remain the same. In theory, the banking system reduces excess reserves-but only by expanding loans and the money supply in a way that increases required reserves by an equivalent amount. The key is that the Fed will have to drain reserves when the economy begins to recover if it is to prevent a rapid acceleration of inflation. That necessity drives the current discussion of exit strategies. ${ }^{8}$

The ease with which the Fed can reduce the size of its balance sheet in the future depends on many factors, including the term of its loan portfolio, the quality of assets that it holds outright, and the market's appetite for repurchasing these

8 See Bernanke (2009). financial instruments. The authorization for the ultimate size of new programs varies and has grown since the beginning of the crisis. Table 2 lists each new program and the upper limit authorized as of January 28, 2009. Of course, in some cases the limits will be determined by the available assets and/or by the demand for the program. (Note that there are zero assets in the MMIFF, which has an authorization of $\$ 540$ billion.)

When the time comes to shrink the monetary base, the Fed could allow the lending programs to expire as loans mature and sell the assets that it holds outright. If the crisis is over, the assets should be priced in the market and the Fed should expect to recover most of its investment in such assets.

Inflation does not appear to be a risk in the current environment: The economy is in recession. Inflation is falling and is not expected to return before the recession ends. If inflation resumes but the economy does not recover, policymakers will face a difficult choice. Monitoring the size and composition of the monetary base as the economy recovers will help us understand what actions are needed (and should be taken) by the Fed and the Congress to prevent a return to a high-inflation economy. 


\section{REFERENCES}

Anderson, Richard G. and Rasche, Robert H. "Retail Sweep Programs and Bank Reserves, 1994-1999.” Federal Reserve Bank of St. Louis Review, January/February 2001, 83(1), pp. 51-72; http://research.stlouisfed.org/publications/review/ 01/0101ra.pdf.

Anderson, Richard G. and Rasche, Robert H. “A Revised Measure of the St. Louis Adjusted Monetary Base." Federal Reserve Bank of St. Louis Review, March/April 1996, 78(2), pp. 3-14; http://research.stlouisfed.org/publications/review/ 96/03/9603ra.pdf.

Balbach, Anatol and Burger, Albert E. "Derivation of the Monetary Base.” Federal Reserve Bank of St. Louis Review, November 1976, pp. 2-8; http://research.stlouisfed.org/publications/review/ 76/11/Derivation Nov1976.pdf.

Bernanke, Ben S. "The Crisis and the Policy Response.” The Stamp Lecture, London School of Economics, London, England, January 13, 2009; www.federalreserve.gov/newsevents/speech/ bernanke20090113a.htm.

Porter, Richard D. and Judson, Ruth A. "The Location of U.S. Currency: How Much Is Abroad?” Federal Reserve Bulletin, October 1996, 82, pp. 883-903; www.federalreserve.gov/paymentsystems/coin/ 1096lead.pdf.

Stevens, Edward J. "Required Clearing Balances.” Federal Reserve Bank of Cleveland Economic Review, Quarter IV 1993, 29(4), pp. 2-14; http://clevelandfed.org/Research/Review/1993/ 93-q4-stevens.pdf.

Thornton, Daniel L. “The Fed, Liquidity, and Credit Allocation.” Federal Reserve Bank of St. Louis Review, January/February 2009, 91(1), pp. 13-21; http://research.stlouisfed.org/publications/review/ 09/01/Thornton.pdf. 
